\title{
Whatever happened to group dynamics in the scientific study of groups?
}

\author{
Sandra G.L. Schruijer \\ Utrecht School of Governance, Utrecht University, Utrecht, The Netherlands
}

\begin{abstract}
Purpose - The purpose of this study is to explore whether a group dynamics perspective still exists in the scientific study of groups and what factors may account for the current situation.

Design/methodology/approach - Alongside reflections based on my professional experience, I have analyzed the main academic journals that publish group research.

Findings - A group dynamics perspective is almost totally absent in the scientific study of groups. Contributing factors to this state of affairs are disciplinary developments in psychology (e.g. individualization, experimentalization and specialization), the demise of the status of psychoanalysis, changes in the meaning and manifestation of the "group," and effects of New Public Management.

Originality/value - The study offers a critical perspective on current group research practices and considers these in a larger (social and historical) context. It advocates a group dynamics perspective for the study of groups, based on systems-psychodynamic insights.
\end{abstract}

Keywords Group dynamics, Group research practices, Group-level research, System-psychodynamics

Paper type Viewpoint

\section{Introduction}

Does scientific research into group dynamics still exist? This question intrigued me after I learned the difference between the terms "group processes" and "group dynamics." That there is a difference only dawned on me after I had been teaching courses on group dynamics for many years. I began to realize that a group dynamics perspective is hardly represented in scientific research. Questions of course are "what is scientific research" and "what is group dynamics." The first question can be answered by referring to research that is published in academic journals. The answer to the second question to me is the emotional, often unconscious dynamics at the level of the "group-as-a-whole." These are by no means exhaustive or per definition satisfactory answers but they fit the framework of my analysis.

The study of group dynamics traditionally belongs to social psychology, although group research is also being conducted within organizational psychology, sociology and anthropology. In this article, I restrict myself primarily to social and organizational

(C) Sandra G.L. Schruijer. Published by Emerald Publishing Limited. This article is published under the Creative Commons Attribution (CC BY 4.0) licence. Anyone may reproduce, distribute, translate and create derivative works of this article (for both commercial and non-commercial purposes), subject to full attribution to the original publication and authors. The full terms of this licence may be seen at http://creativecommons.org/licences/by/4.0/legalcode

Translated and adapted from Schruijer (2020). Over de afwezigheid van een groepsdynamisch perspectief in het wetenschappelijk onderzoek naar groepen. Groepen: Tijdschrift voor Groepsdynamiek en Groepspsychotherapie, 4, 29-39.

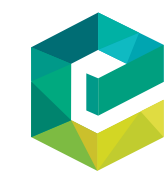

Team Performance Management: An International Journal Vol. 27 No. $3 / 4,2021$ Vol. 27 No. $3 / 4,2021$
pp. $229-239$ pp. $229-239$
Emerald Publishing Limited 1352-7592 
TPM

$27,3 / 4$

230 psychology - the discipline(s) in which I was trained. Classics in group dynamics that I was confronted with during my studies are, for example, the books by Cartwright and Zander (1968), Shaw (1981) and (still popular) Forsyth (1990). Directly after the Second World War, when group research started to blossom, the ideas of psychoanalyst Wilfred Bion were seen as very promising for social psychological research into groups (Lindzey, 1954). In this article, I want to find out whether and to what extent a group dynamics perspective, based on important notions derived from psychoanalysis, established itself in the study of group processes. I also will pay attention to factors that are likely to have contributed to the depicted current state of affairs. I will start with sketching my background and development as a group researcher.

\section{My background and development as a group researcher}

I was educated in social and organizational psychology during the end of the 70 s, beginning of the 80s of the past century, especially as a researcher with a positivistic philosophy of science. It meant working with laboratory experiments and surveys. As a student, I was fascinated by classic studies such as those of Muzafer Sherif, Stanley Milgram, Solomon Asch and was socialized in the European admiration of - what I thought was - "modern" social (predominantly American) psychology. Organizational psychology offered insights into the dynamics of workgroups in practice. Besides the iconic mining studies that contributed to the development of socio-technical thinking, and the Hawthorne experiments, there was ample attention for more recent experimental and survey research into phenomena such as job satisfaction, group rewards and feedback systems. Again, the hotshots seemed all to work in the US. As a young lecturer, I taught classes in, among others, organizational psychology, decision-making processes and group dynamics. In the latter course, I spoke of studies done within experimental social psychology (on, for example, social influence, leadership and group decision-making). $\mathrm{My} \mathrm{PhD}$ addressed the determinants and processes of conflict between mostly real groups, and was based on partly experimental and partly survey-research, taking context into consideration, yet adopting an individual level of analysis, while no attention was given to non-conscious processes (apart from a dutiful short paragraph on psychodynamic theories of intergroup relations (Schruijer, 1990)).

I became painfully aware that, actually, I only understood very little of "real" group dynamics, when participating in a system-psychodynamic and experience-based program on change in and of organizations. Reflecting on the group dynamics as they occurred in the context of the program, for example, in so-called learning groups ("double task," à la Harold Bridger, 1990), was a main activity. I was confronted with the fact that although my head was full of concepts, I understood little of what was going on in the here-and-now of my group. To be honest, I was shocked that the dynamics of the group did not reveal themselves neatly in terms of concepts that were familiar to me. Moreover, I found it extremely difficult to articulate my experiences. Without the concepts, I was without the right words and felt powerless. It also dawned on me how quickly academics bring in their well-known concepts to "understand" what is going on, thus glossing over the uniqueness and complexity of the dynamics in the here-and-now that cannot be captured by existing concepts (as these are always a reduction of reality). Ever since I try to find the way inwards (with myself and others). I have become an advocate of experiential learning and I developed a great interest in psychoanalysis and system-psychodynamics (Vansina and Vansina-Cobbaert, 2008; Fotaki, Long and Schwartz, 2012) - an interest that simply could not develop during my university education as almost nothing positive was said of Sigmund Freud and his successors. I was educated as a Scientific Researcher and Freud, surely, he was not a real scientist, was he?

In the system-psychodynamic program, I participated in, I learned about classic concepts such as the dynamic unconscious and, repression, as formulated originally by Sigmund 
Freud (Gay, 1995), as well as the paranoid-schizoid and the depressive position as developed by Melanie Klein (Segal, 1988). Above all, I got acquainted with the work of those psychoanalysts who were also interested in the emotional life of groups and organizations, such as Wilfred Bion (with his notion of "basic assumptions," referring to unconscious and ineffective modes of group functioning because of task-related tensions (Bion, 1961); his recommended "stance" as a psychoanalyst, also relevant for an action researcher or process consultant, namely, "without memory, desire or understanding" (Bion, 1970)), Isabel Menzies-Lyth (regarding "social defenses," describing how task-induced anxieties manifest themselves in dysfunctional organizational routines, structures and cultures, often contradicting values and beliefs at the conscious level (Long, 2008; Stein, 2007, 2019)), Elliott Jaques (regarding his concept of "time span of discretion" and how an organization's hierarchy should reflect the variation in cognitive complexity of its members (Jaques, 1989)) and Harold Bridger (with his memorable phrase "sharing, comparing and finding out" so as to engage in joint sense making and "start from where the client is" (Vansina and VansinaCobbaert, 2008)). Not the individual and his or her private life is the unit of analysis and intervention, but the group or organization, in a work context: a system-psychodynamic perspective.

Thus, I gained a sense of the emotional and dynamic life of the group in its context that is a function of the fundamental conflict between the individual and his or her group. "The individual is a group animal at war, both with the group and with those aspects of his personality that constitute his "groupishness"' (Bion, 1961, p. 168). Much of these dynamics involve non-conscious processes that can surface by sharing experiences group members have and a joint reflection thereof. In an appropriate setting. With the aim of understanding what is happening at the group level and learning from it. A group is more than the sum of individuals (although it is individuals who have feelings and experiences), while individual behaviors can be an expression of the group climate (rather than referring to individual-level phenomena). Naturally, group members are also individuals with their idiosyncrasies, yet a group dynamics perspective concerns questions such as how the group works with these differences or how individuals with certain characteristics ended up in the group to start with. Thus, a group level of analysis is embraced, a level at which forces from higher system levels (interactions with other groups, influences from the organization and developments in society) can impinge and become expressed in the group dynamics.

A group dynamics researcher does not adopt a distant position so as to observe sharply or measure precisely, a position that does not allow for sensing the emotional life of the group. The idea is to engage in a relationship with the group and use oneself as an instrument to gauge the deeper dynamics. During reflective moments (either in a special reflective session or while working on the task) the researcher shares his or her observations and/or experiences and invites the others to share theirs so as to jointly come to a deeper understanding of what is going on. Thus, the researcher adopts a subjective position in observing the group and oneself (in their interaction), and arrives at a deeper insight together with the group members. Truly a different perspective than one that fits positivism in which universal theories are developed about (and not with) the average group (or group member) in a vacuum - an average group that one never encounters in real life and that never exists cut off from context. Instead of an experiment or a survey, the researcher chooses for observation, interview, largely within the frame of action-research. The focus is on $N=1$, in context, with the purpose of Verstehen rather than Erklären (Schruijer, 2020a, 2020b, 2021). 
TPM

$27,3 / 4$

My current research addresses the dynamics of groups that consist of group members who represent different organizations (Schruijer, 2008; Schruijer and Vansina, 2008). For example, in the context of regional development, developing transport infrastructure, collaboration between health care organizations, etc. (Schruijer, 2020a, 2020b). These organizations come together around tables, in working conferences or (as it is called nowadays) in "living labs" or "hubs." As an action-researcher or process consultant, I sometimes conduct interviews, yet prefer to be present there where parties actually come together in the here-and-now, so as to observe (and when so agreed upon to intervene) and get a sense of the deeper group dynamics (Schruijer, 2021). I bring in my observations and engage in reflective conversations to become aware of the dynamics, what its sources and context are and how to address the dynamics if so desired. Further, I play "real life" multiparty simulations to allow participants to experience the group dynamics and learn from these (Vansina, Taillieu and Schruijer, 1998), where questionnaires, besides observations, also can help in finding out what is going on (Curşeu and Schruijer, 2018, 2020). Studying group dynamics for me means working with existing groups, taking into account the context, in search of conscious and unconscious behavioral patterns and underlying tensions, using an interpretative approach.

\section{Current group research practices}

To find out about the current practices of group research, I make a distinction between two traditions. The first aims to unearth behavioral patterns of the group, in its totality, by engaging in an analysis at the level of the group - studies into the "group-as-a-whole" (Ettin, Cohen and Fidler, 1997; Horowitz and Perlmutter, 1953). The group is generally observed, possibly complemented with interviews and questionnaires. The research involves real groups, in context. Classic examples are the Hawthorne studies (Roethlisberger and Dickson, 1939), where formal and informal groups were studied; Kurt Lewin's Field Theory (Lewin, 1951) and his group experiments (for example, into leadership (Lewin, Lippitt and White, 1939)); and Muzafer Sherif's field experiments on competition and collaboration between groups during a summer camp (Sherif, 1966). I position theory and research from a psychodynamic perspective, searching for non-conscious group dynamics, within the tradition of the "group-as-a-whole." Think of Bion (1961) and Foulkes (1946). This is what I mean with a group dynamics perspective. I also clearly include the phenomenon of "groupthink" (Janis, 1972) (many do not know that Irving Janis, like so many others of his generation, was (also) trained in psychoanalysis), as I do Edgar Schein's (1986) clinicalinterpretative perspective on organizational culture, who locates its kernel in the layer of non-conscious "basic assumptions" (NB: Schein's basic assumptions have a different meaning than those of Bion). These studies aim to understand the individual case in context and are largely interpretative (sometimes field experimental).

The second tradition is wholly positivistic in nature and which I would like to name as "group-as-an-aggregate" (Horowitz and Perlmutter, 1953). Researchers within this tradition label their research as "group research" or research into "group processes," yet the group is treated in the analyses as a sum of individuals. It is the individual that is the unit of observation. Moreover, experimental social-psychological research often uses so-called "ad hoc" groups, consisting of individuals who do not know one another yet have to jointly carry out a task or fake groups in which individuals are under the illusion there are other group members to work with while in reality, the individual is on its own. Such practices emerged in the generation after Lewin and have been criticized in the decades following (Steiner, 1974; Danziger, 2000; Stam et al., 2000; Greenwood, 2004). Nowadays group members' responses are often aggregated so that cross-level research can be conducted. As social psychology has been criticized for its a-contextual nature (Jahoda, 2016; Pettigrew, 2018), 
this seems laudable. A generally accepted formula is used to decide whether aggregation is allowed (James et al., 1984). The value obtained via this formula is a measure of agreement. In other words, only when group members sufficiently agree, can aggregation take place. Thus, the group is conceptualized as a homogenous entity. Although criticisms of this formula have been published (Kessler, 2019), and although interesting work is done on true group-level dispersion variables (De Jong and Dirks, 2012), also using true group-level dependent variables (Curşeu, 2003; Curşeu et al., 2007), these aggregation practices are very common within social psychology, yet also in organizational psychology, where much more often real groups are being studied, mostly labeled as "teams." The term "group dynamics," by the way, is hardly used anymore, in favor of terms such as "emergent processes" and "emergent states" (Marks et al., 2001; Ilgen et al., 2005).

As is evident from the preceding, over time I came to reserve the term group dynamics for research done within the first tradition, especially when there is attention to nonconscious dynamics. Such group dynamics do not seem to play a role (anymore) in academic research on groups or in academic education (Schruijer, 2013). To test this impression further, I conducted an analysis of 12 leading academic journals that are known for publishing group research (among other themes), namely, 2 general social-psychological journals (Journal of Personality and Social Psychology, European Journal of Social Psychology); 3 typical "group” journals (Group Dynamics, Small Group Research, Group and Organization Management), a journal with system-psychodynamic roots (Human Relations), 4 organizational psychology journals (European Journal of Work and Organizational Psychology, Journal of Occupational and Organizational Psychology, Journal of Organizational Behavior, Journal of Applied Psychology) and 2 sociological journals that in the past published some classics in group research (American Sociological Review and American Journal of Sociology).

I went through all the issues in the period of July 2019 till July 2020, and assessed, which type of group research was reported. Of the approximately 600 articles published, 100 concerned group research (or claimed to do so). Of these 100, 14 involved existing groups while also making analyses at the group level. Five used observations (with four observing existing groups), two of which I can call group dynamic, addressing the emotional climate yet without trying to understand deeper non-conscious dynamics. In total, 39 used the aggregation practice described above. All others used an individual level of analysis (without aggregation). Two studies, that can be categorized under the label "group dynamics," out of a total of 100 group studies, appears to be minimal.

Another illustration involves a citation-analysis of Bion's classic book Experiences in groups (1961) over the years (Schruijer and Curşeu, 2014). In it, Bion describes his insights regarding the unconscious group dynamics that emerge as group members work together and deal with the tensions arising from the task. These dynamics can prevent effective group work although group members themselves may experience that they are successful. Unconscious emotional dynamics emerge in, for example, an excessive dependency on the leader, a tendency to fight or flee for a real or imaginary enemy or the hope that a subgroup will resolve the difficulties. The period studied involves 1988 till 2012. We categorized the literature into: clinical/therapeutic, organization and management and social psychology literature. Our analysis shows that Bion's work is cited less over the years (which is logical), yet differently so in the different disciplines. In the clinical/therapeutic literature the number of citations is almost halved (from 109 to 65), equally so in the organization and management literature, where Bion is cited less frequently than in the clinical-therapeutic literature (from 52 to 28), while in social psychology, where Bion is least cited compared to the other literatures, the number of citations is reduced to zero (from 28 to nil). 
Hence, I can conclude that there is hardly any group research published in academic journals that I would call group dynamics. Such a conclusion is corroborated by a review article that discusses the contribution of psychodynamic thinking toward the study of groups yet cites only a few recent articles (McLeod and Kettner-Polley, 2004). Studies using the aggregation practice I do not consider "group-as-a-whole" research because only those groups are included in which group members agree. What does that imply - does a group only consist of like-minded people? This view would undermine the true nature of the group - a healthy one that is, that is composed of different individuals who simultaneously try to balance their need for autonomy and for belonging. Dynamics, ambivalence and conflict are the very essence of groups (think of Bion's description of a group). By the way, much of the reported research is very interesting and has merits of its own, yet, it is the lack of dynamic understanding that I want to address in this paper.

A few qualifications. I also went through many issues of the Journal of Abnormal and Social Psychology, a predecessor of various current psychological journals, notably the 30s through to the 60 s of the past century. In this period, group dynamics research, with attention to unconscious dynamics, does not really feature either. Nevertheless, many "group-as-a-whole" classics are reported during this period. In addition, as mentioned, among the first generations of post-war social psychologists there was an interest in psychoanalysis and various scholars were also trained in it (e.g. Herbert Kelman, Morton Deutsch, Harold Gerard, Irving Janis, Chris Argyris, Elliot Aronson and Solomon Asch, see for example Greenwood, 2004). Moreover, during this period, collaboration with sociologists was common, for example, in educating social psychologists (Oishi et al., 2009). Noteworthy is further that the term "group dynamics," which was used in the earlier periods of group research, by now almost has disappeared from the academic psychological vocabulary. However, it also needs mentioning that within organization sciences an interest in a psychoanalytic perspective is emerging (for example Fotaki et al., 2012).

\section{What is the broader context of these developments?}

Various factors are likely to have contributed to the waning interest in a group dynamics perspective, based on psychodynamics (or perhaps, better, socio-dynamics (Long, 2013)). One concerns the establishment of social psychology as a science, which went together with experimentalization, decontextualization, individualization and specialization. These developments occurred after World War II, first in the powerful US (where the so-called "modern social psychology was born") and from there in Europe (where a different, less individualistic prewar tradition existed (Farr, 1996)). Even though European social psychologists wanted to develop an alternate to the dominance of postwar American social (and individualistic) psychology, they only succeeded to a limited extent (Schruijer, 2012).

Further, many experimental social psychologists entertained (and still do) an aversion psychoanalysis and group dynamics (Schruijer and Curşeu, 2014) (in contrast to the generation directly after World War II, who, as said, were open to and received training in psychoanalytic thinking). The European social psychologists deliberately chose the term "experimental" for the name of their European association to denote that they were true scientists. They wanted to make a clear distinction between serious researchers and those practicing "group dynamics, psychoanalysis and cheap social psychology" (Schruijer and Curşeu, 2014, p. 240). This aversion is a reflection of the demise of the status and influence of psychoanalysis in science and society, in favor of cognitive sciences and (neuro) biology.

Moreover, the actual meaning and manifestation of "group" has changed. Workgroups are less sustainable - the mobility of people has increased, organizations continuously 
change - how stable is the workgroup nowadays in terms of its membership? Groups have become more temporary (think of project teams) while the diversity (demographic, role and organization) within groups has increased. Maybe this explains the decreased attention for "the group" and group dynamics, although the use of the term "team" has exploded, at the expense of the term "group." With the word of "team," the fundamental tension between the individual and the group is magically "resolved" by stating "there is no I in a team". However, a group cannot function if individual interests are being suppressed or neglected. Tensions among individuals and between the group on the hand one and the individual on the other are normal in group work. Avoiding these tensions is indicative of collusion or force, perhaps, fitting the original meaning of the word "team" - it is derived from the old English "téam" ("set of draught animals") and cognate to the German word "Zaum" and the Dutch word "toom." "Intomen" in Dutch means "to restrain." Restraining the individual so "there is no I in the team?" Needless to say, a group dynamics perspective on teams is missing too.

Finally, I want to point to changes in the institution where scientific research and education is being practiced - the university. As a consequence of ideas derived from New Public Management, universities and academics are subject to comparison - to that end, their performance is constantly measured, based on indicators that can be measured easily: numbers of publications, numbers of students, citation-indices, etc. The general rule is: the more the better. Experimental research with ad hoc groups and at an individual level of analysis is simply easier to carry out and to be published more swiftly than in-depth, observational research on existing groups with the aim of fathoming their deeper, emotional dynamics.

\section{Conclusion and reflection}

A group dynamics perspective in the meaning I have described above seems to be largely absent in the scientific study of groups. By far most of the group research is conducted within the empirical-analytical tradition, which characterizes almost all research within psychology. Interpretative research is carried out, but substantially less so. The kind of group dynamics research that I propagate is quite unique (but not new) as the researcher works with his or her subjectivity. Anthropology harbors a few self-reflexive approaches in which the researcher uses his or her experiences and emotions (Zilber and Zanoni, 2020), yet, a group dynamics researcher also shares his or her sense-making with the group members so as to arrive at a richer and joint meaning. One's own subjectivity is used to understand the dynamics. Quite unusual or basically "not done" in the dominant empirical-analytic academic climate. Yet, fitting research that aims to develop "actionable knowledge" (Argyris, 1996), such as action-research. Interventions, besides contributing toward desired change, on the whole, also lead to a deeper understanding.

A group dynamics perspective apparently never featured prominently in group research. Students in psychology, by the way, did come into contact with it through their curriculum (Schruijer, 2013), yet these times belong to history. The general disappearance of this perspective constitutes an impoverishment of the scientific study into and education about groups. Also, in the domain of training and development, practices involve "team building" rather than understanding and working with group dynamics. Individual differences are brought to awareness (through questionnaires with sometimes dubious psychometric qualities) "because it helps if group members know that they are different [...]," yet it remains unspecified to what extent these differences are relevant for realizing the group task. Instead of making an inventory of possible differences among the group members, a 
group dynamics perspective aims to come to a deeper understanding why certain differences are represented in the group, what these differences do with the group and how the group deals and can deal with these so as to improve group performance and members' well-being.

Prior to my group dynamics initiation, I knew a lot but understood little. Later on, I embraced psychodynamic perspectives, as well as experiential learning, in my research, my teaching and my practice. Through using my subjectivity and engaging in a joint process of sense-making, with the members of the group under study, through not accepting conscious "text" at face value while trying to open up to context, I begin to gain a deeper understanding of the emotional group life. I encounter groups that seem satisfied with their group work, both in terms of process and outcomes, yet they avoid all tensions and do not make use of each others' diverse talents - a collusion they are not aware of. I see groups that fall apart and "solve" the situation by finding a black sheep among themselves, not being aware of how larger forces, which they cannot confront or control, induce them to start fighting one another. Other groups come to mind that seem to evolve around a few narcissistically inclined individuals, yet upon closer inspection (and reflection), these individuals basically express a deeper narcissistically group culture, sustained by a context that is very performance-oriented. I further have become more aware over time that the action researcher, process consultant or lecturer can be confronted with hostility from the group while underneath it one can find group members' own insecurities and/or internal disagreements that they find hard to confront; if those hostilities are contained, they can start addressing their internal concerns and develop as a group (and as individuals). How to get in touch with these deeper dynamics if one only collects cross-sectional data, uses ad hoc groups, aggregates individual data and adopts a distant position?

With students and clients, I play simulations, engage in improvising, join their group meetings and help them observe and reflect on their own group dynamics. They plunge in with enthusiasm. Hopefully, they catch at least a glimpse of what has become so meaningful to me. I still conduct an experiment once in a while or collect survey data, but through engaging in action-research and doing research with (rather than on) groups under consideration, I hope that my work is value-able rather than value-free. I may not be a famous scientist, my h-index is pretty modest, I may be a "cheap social psychologist" to some, yet, more than ever, I feel I can get a grasp of group life (although one's learning never ends). Also, I can be of help. How fulfilling that is.

\section{References}

Argyris, C. (1996), "Actionable knowledge: design causality in the service of consequential theory”, The Journal of Applied Behavioral Science, Vol. 32 No. 4, pp. 390-406.

Bion, W. (1961), Experiences in Groups and Other Papers, Tavistock Publications, London.

Bion, W. (1970), Attention and Interpretation, Tavistock Publications, London.

Bridger, H. (1990), "Courses and working conferences as transitional learning institutions", in Trist, E. and Murray, H. (Eds), The Social Engagement of Social Science (Vol 1. The Socio-Psychological Perspective), The University of PA Press, Philadelphia.

Cartwright, D. and Zander, A. (1968), Group Dynamics; Research and Theory, Harper and Row, New York, NY. 
Curşeu, P. (2003), Formal Group Decision-Making: A Socio-Cognitive Approach, ASCR Press, Cluj-Napoca.

Curşeu, P. and Schruijer, S. (2018), "Cross-level dynamics of collaboration and conflict in multi-party systems: an empirical investigation using a behavioural simulation", Administrative Sciences, Vol. 8 No. 3, p. 26, doi: $10.3390 /$ admsci8030026.

Curşeu, P. and Schruijer, S. (2020), "Participation and goal achievement of multiparty collaborative systems dealing with complex problems: a natural experiment", Sustainability, Vol. 12 No. 3, p. 987, doi: 10.3390/su12030987.

Curşeu, P., Schruijer, S. and Boros, S. (2007), "The effects of groups' variety and disparity on groups' cognitive complexity”, Group Dynamics: Theory, Research, Practice, Vol. 11 No. 3, pp. 187-206.

Danziger, K. (2000), "Making social psychology experimental: a conceptual history, 1920-1970”, Journal of the History of the Behavioral Sciences, Vol. 36 No. 4, pp. 329-347.

de Jong, B. and Dirks, K. (2012), "Beyond shared perceptions of trust and monitoring in teams: implications of asymmetry and dissensus", Journal of Applied Psychology, Vol. 97 No. 2, pp. 391-406.

Ettin, F., Cohen, B. and Fidler, J. (1997), "Group-as-a-whole theory viewed in its 20th-century context", Group Dynamics: Theory, Research, and Practice, Vol. 1 No. 4, pp. 329-340.

Farr, R. (1996), The Roots of Modern Social Psychology, Oxford University Press, Oxford.

Forsyth, D. (1990), Group Dynamics, 2nd ed., Wadsworth, Belmont, CA.

Fotaki, M., Long, S. and Schwartz, H. (2012), "Psychoanalytic perspectives on organizations: what can psychoanalysis offer organization studies today?”, Organization Studies, Vol. 33 No. 9, pp. 1105-1255.

Foulkes, S. (1946), “On group analysis”, International Journal of Psychoanalysis, Vol. 27, pp. 46-51.

Gay, P. (Ed.) (1995), The Freud Reader, Vintage Publishing.

Greenwood, J. (2004), The Disappearance of the Social in American Social Psychology, Cambridge University Press, New York, NY.

Horowitz, M. and Perlmutter, H. (1953), "The concept of the social group”, The Journal of Social Psychology, Vol. 37 No. 1, pp. 69-95.

Ilgen, D., Hollenbeck, J., Johnson, M. and Jundt, D. (2005), "Teams in organizations: from input-processoutput models to IMOI models", Annual Review of Psychology, Vol. 56 No. 1, pp. 517-543.

Jaques, E. (1989), Requisite Organization: The CEO's Guide to Creative Structure and Leadership, Cason Hall and $C_{0}$ Publishers.

Jahoda, G. (2016), "Seventy years of social psychology: a cultural and personal critique", Journal of Social and Political Psychology, Vol. 4 No. 1, pp. 364-380.

Janis, I. (1972), Victims of Groupthink, Houghton Mifflin, Boston.

James, L., Demaree, R. and Wolf, G. (1984), "Estimating within-group interrater reliability with and without response bias", Journal of Applied Psychology, Vol. 69 No. 1, pp. 85-98.

Kessler, S. (2019), "Are the costs worth the benefits? Shared perception and the aggregation of organizational climate ratings”, Journal of Organizational Behavior, Vol. 40 Nos 9/10, pp. 1046-1054.

Lewin, K. (1951), Field Theory in Social Science, Harper, New York, NY.

Lewin, K., Lippitt, R. and White, R. (1939), "Patterns of aggressive behavior in experimentally created social climates", Journal of Social Psychology, Vol. 10, pp. 271-279.

Lindzey, G. (1954), Handbook of Social Psychology (Vol. 1: Theory and Method), Addison-Wesley, Cambridge, MA.

Long, S. (2008), The Perverse Organization and Its Deadly Sins, Karnac, London. 
Long, S. (2013), Socioanalytic Methods: Discovering the Hidden in Organisations and Social Systems, Karnac, London.

McLeod, P. and Kettner-Polley, R. (2004), "Contributions of psychodynamic theories to understanding small groups”, Small Group Research, Vol. 35 No. 3, pp. 333-361.

Marks, M., Mathieu, J. and Zaccaro, S. (2001), "A temporally-based framework and taxonomy of team processes”, Academy of Management Review, Vol. 26 No. 3, pp. 530-547.

Oishi, S., Kesebir, S. and Snyder, B. (2009), "Sociology: a lost connection in social psychology", Personality and Social Psychology Review, Vol. 13 No. 4, pp. 334-353.

Pettigrew, T. (2018), "The emergence of contextual social psychology", Personality and Social Psychology Bulletin, Vol. 44 No. 7, pp. 963-971.

Roethlisberger, F. and Dickson, W. (1939), Management and the Worker, Harvard University Press, Cambridge, MA.

Schein, E. (1986), Organizational Culture and Leadership, Jossey-Bass, San Francisco.

Schruijer, S. (1990), Norm Violation, Attribution and Attitudes in Intergroup Relations, Tilburg University Press, Tilburg.

Schruijer, S. (2008), "The psychology of interorganizational relations", in Cropper, S., Ebers, M., Huxham, C. and Smith Ring, P. (Eds), The Oxford Handbook of Interorganizational Relations, Oxford University Press, New York, Oxford, pp. 417-440.

Schruijer, S. (2012), "Whatever happened to the term 'European' in European social psychology? A study of the ambitions in founding the European association of experimental social psychology", History of the Human Sciences, Vol. 25 No. 3, pp. 88-107.

Schruijer, S. (2013), "Are we losing the group in the study of group dynamics? Three illustrations", in Vansina, L. (Ed.), Humanness in Organizations: A Psychodynamic Contribution, Karnac, London, pp. 71-89.

Schruijer, S. (2020a), "Developing collaborative interorganizational relationships: an action research approach", Team Performance Management: An International Journal, Vol. 26 Nos 1/2, pp. 17-28.

Schruijer, S. (2020b), "Over de afwezigheid van een groepsdynamisch perspectief in het wetenschappelijk onderzoek naar groepen”, Groepen: Tijdschrift Voor Groepsdynamiek en Groepspsychotherapie, Vol. 4, pp. 29-39.

Schruijer, S. (2021), "The group dynamics of interorganizational relationships", Oxford Research Encyclopedia of Psychology, doi: 10.1093/acrefore/9780190236557.013.512.

Schruijer, S. and Curşeu, P. (2014), "Looking at the gap between the social psychological and psychodynamic perspectives on group dynamics historically", Journal of Organizational Change Management, Vol. 27 No. 2, pp. 232-245.

Schruijer, S. and Vansina, L. (2008), "Working across organizational boundaries: understanding and working with the psychological dynamics", in Vansina, L. and Vansina-Cobbaert, M. J. (Eds), Psychodynamics for Consultants and Managers: From Understanding to Leading Meaningful Change, Wiley, London, pp. 390-410.

Segal, H. (1988), Introduction to the Work of Melanie Klein, Karnac Books, London.

Shaw, M. (1981), Group Dynamics, 3rd ed., McGraw-Hill, New York, NY.

Sherif, M. (1966), In Common Predicament: Social Psychology of Intergroup Conflict and Cooperation, Houghton Mifflin, Boston.

Stam, H., Radtke, H. and Lubek, I. (2000), "Strains in experimental social psychology: a textual analysis of the development of experimentation in social psychology", Journal of the History of the Behavioral Sciences, Vol. 36 No. 4, pp. 365-382.

Stein, M. (2007), "Oedipus rex at Enron: leadership, oedipal struggle, and organizational collapse", Human Relations, Vol. 60 No. 9, pp. 1387-1410. 
Stein, M. (2019), “The lost good self: why the whistleblower is hated and stigmatized”, Organization Studies, doi: 10.1177/0170840619880565.

Steiner, I. (1974), "Whatever happened to the group in social psychology?", Journal of Experimental Social Psychology, Vol. 10 No. 1, pp. 93-108.

Vansina, L. and Vansina-Cobbaert, M.J. (2008), Psychodynamics for Consultants and Managers: From Understanding to Leading Meaningful Change, Wiley, London.

Vansina, L., Taillieu, T. and Schruijer, S. (1998), “Managing' multiparty issues: learning from experience", in Pasmore, W. and Woodman, R. (Eds), Research in Organizational Change and Development, JAI Press, Greenwich, CT, Vol. 11, pp. 159-183.

Zilber, T. and Zanoni, P. (2020), "Templates of ethnographic writing in organization studies: beyond the hegemony of the detective story", Organizational Research Methods, pp. 1-34, doi: 10.1177/ 1094428120944468.

\section{Corresponding author}

Sandra G.L. Schruijer can be contacted at: s.g.1.schruijer@uu.nl

For instructions on how to order reprints of this article, please visit our website: 